\title{
Daily life astronomy activity and its contribution to children and educators in science education
}

\author{
Akihiko Tomita ${ }^{1, *}$ \\ ${ }^{1}$ Faculty of Education, Wakayama University, Wakayama City 640-8510, Japan
}

\begin{abstract}
Daily life astronomy activity in nurseries and after school care clubs has many aspects to improve children's and educator's scientific views and skills. Though these activities are casual and ordinary ones for many nurseries and after school care clubs, aspects of science education are found in many ways reflecting the activity referring to the UNAWE Evaluation Guide. This indicates that if we intend to promote science education in nurseries and preschools, we do not necessarily have to introduce new activity, but that the formative assessment to pick up science in daily life activities is sufficient. This can encourage educators to be selfconfident in implementing science education. The improvement of selfconfidence is observed in teacher-training students of primary and preschool education during university class when they learned that they already had skills for daily life astronomy education. Thus, daily life astronomy education is not only an interesting and exciting activity for children but it also contributes to improving the educator's confidence and hence their skills of science education.
\end{abstract}

\section{Introduction}

The importance of science education, including astronomy education, in early childhood has been stressed by many researchers and educators. In addition to the small number of educators practising science education, there is a serious problem: early childhood and primary educators are no self-confident in science education, especially astronomy education. This is often the case for the teacher-training students. Therefore, it is important to let the students gain self-confidence during the teacher training.

I have visited nurseries, kindergartens, and after-school care clubs for primary school pupils more than a hundred times for more than ten years [1]. During the activity, my collaborators and I found that during the casual activity and during ordinary life after the activity, children showed and improved their own basic scientific skills and educators also improved their point of view in science. In my class for teacher-training students, I introduced above findings to the students who are no self-confident in science education to show that most students already have basic skills and experience for implementing science education.

\footnotetext{
* Corresponding author: atomita@center.wakayama-u.ac.jp
} 
This paper is organized as follows. In section 2, the outline of the activity at nurseries and other places, and findings of the basic scientific skills in children and educators are given. In section 3 , the results of the questionnaire are used to show that student attitude toward science changed after the class with examples of daily life science and astronomy education. In section 4 , a brief summary and conclusion are given.

\section{Activity at Nursery and After School Care}

The activity "Uchu no Ohanashi" meaning Story about Universe in Japanese, is 45-minute session including talk and hands-on activity in the room for about 80 to 100 children aged three to six years old at nursery and kindergarten. Sometimes I have held one to two-hour outdoor sessions in the evening watching the sky at nursery and after school care club $[2,3]$.

During the activity, I recorded the voices of children and later wrote the voice down. The recorded voices were examined whether they were related to basic scientific skills including enjoyment, inspiration, curiosity, devotion, asking, observing carefully, expressing what they feel in words, trying to interpret, exchanging their idea of interpretation. This examination is the formative assessment referring to EU Universe Awareness (UNAWE) Evaluation Guide [4]. After the activity, I also held one-hour conference to reflect the activity with nursery educators. Below I introduce examples that show the basic scientific skills.

I introduced ten kinds of cloud shape over a year, presenting one shape a month at a nursery. After the activity, children got more aware of clouds and educators recorded the change in children's behavior. One day, a boy sitting in the toilet room found clouds moving and shouted, "Clouds are moving." The toilet has a big window facing courtyard of the nursery, and a boy was observing carefully the motion of the clouds with respect to the window frame. Another boy next to him objected to him: "It can't be true. Clouds can't move." "Look!" "Yes, it's true!" They confirmed the cloud moving. According to the nursery educator, children tend to draw cotton-shaped white marks as the clouds and they think the clouds are stable. The educator said that this experience would change their drawing.

After introducing the rainbow in the sky and rainbow-like colour band in the room, an educator got interested in the rainbow deeply. She began to take pictures of the rainbow. In Japan, people say that the rainbow has seven colours, and there are many songs of the seven-colour rainbow for children. She picked up the colours in the rainbow pictures and counted the number of colours trying to confirm the seven colours, and found that the number did not always seem to be seven. She began doubting of the seven colours and wondered about the prejudice.

Another example is when I talked about the setting Sun. I said, "The Sun will be setting like other stars because the Sun is a star." A boy murmured, "Why stars set? The Sun is a star. The Sun sets, but stars..." The educators explained his confusion. He has seen the Sun set. He has seen the Moon set. But he has not seen the stars set. To him, the stars float when night comes. He tried to reunite his own experience and new information.

In the evening session for after school care children, we enjoy beautiful colours of the evening sky. "What colour is the sky?" "Red or orange." "Is that the only colour you see? What else?" "Golden yellow, blue, dark blue, grey..." Question-and-answer stimulates further observation. Finding many colours leads to a richer drawing activity.

Like above, we are surrounded by wonders of nature and we are always using the basic scientific skills, and we are improving the skills through daily life experience. 


\section{Effect on pre-service teachers}

In 2005, I was in charge of the semester class, Young Children's Living Environment, one of the compulsory subjects for kindergarten teacher's license, consisting of 15 classes. The students consisted of those who wanted to be primary and pre-primary school teachers. I intended to include scientific contents into the subject, but students had no self-confident in science education. Therefore, I included the examples I showed in the previous section and other similar examples from literature and materials by other science educators over the semester. At the first class, I took a questionnaire, and at the last class, I took the same questionnaire: What is science to you? By comparing the change in the answers, I see whether the daily life science and astronomy education can strengthen the self-confidence of students to implement the science class in primary school and pre-primary education.

At the first class, 16 students attended the class and all of them answered the questionnaire. Among them, 4 students had a positive and 12 students had a negative view. The negative answers are as follows: "Not familiar things to me." "An image of being difficult." "Seems to be difficult. Must explode during school experiment." "Requires difficult formulae and calculations. Seems to be serious. Only for the strange people." "Calculation and memorization. Opposite to my feelings." "Gene, cell... a very difficult subject that requires very hard study. I don't like the subject of science, so science is a long way off of me." "I studied weather, chemicals, and living things... Science is 'difficult and serious' to me. It is a subject starting from secondary school, and it seems that it is not familiar to children."

At the last class, 17 students attended the class and all of them answered the questionnaire. Among them, 16 students had a positive and 1 student had a neutral view. The sentences of the answer became much longer. The positive answers are as follows: "From the image of scientists processing some chemicals, now I have a new image that science is more familiar with our daily life. I found many 'is it also science?' Our daily life is full of science." "Science deals with many daily life things. In the daily life at nurseries and kindergartens, children improve their own scientific skills in many ways. I understand it from many records of nursing." "Now I have a new image that we can enjoy science in daily life. Daily-life materials can be science materials through educator's idea. Children's casual thinking and interests can be evaluated from the scientific point of view; it is wonderful." "From children's point of view, we can find many things related to science in our daily life. Adults don't ask questions so frequently. But children do. Children feel many wonders. I thought it difficult at first, but now I realize that 'science' is just everyday life." "A difficult image at first, but examples were not difficult and all of them were interesting to me. Now I feel that 'Science = Fun'." "I have a new image that 'science' is what we can learn from the fun activity. I thought 'science' was serious and difficult. Now I think it is fun and interesting." "I had an image that 'science' was difficult and serious. I changed the image, and now I think science is fun and stirs up the interests. An important part of 'science' is the attitude of enjoying." "Interesting. Full of wonders. Daily life environment offers a lot of hints for science." "We contact 'science' without knowing it is science in our daily life. 'Science' is full of fun." "My first impression was that science was difficult and unapproachable. Through this course, I have changed my attitude to science; science is like this? It is interesting! I noticed that many things I have experienced in my daily life were full of science." 


\section{Summary}

As shown in section 2, the daily life science and astronomy education activities stimulate and improve the basic scientific skills of both children and educators. This indicates that if we intend to promote science education in nurseries and preschools, we do not necessarily have to introduce new activity but having formative assessment and evaluation to pick up science in daily life activity is sufficient. This will encourage educators to be self-confident about implementing the science education.

Comparing the answers to the questionnaire of the university class for teacher-training students of primary and pre-primary education, the number of answers of positive attitudes is greatly increasing, the sentence is longer, and contents of the answers are full of admiring the daily life science. This indicates that introducing the daily life science and astronomy activity improve students' self-confidence to implement the science class.

Thus, daily life astronomy education is not only interesting and exciting activity to children but also it contributes to improving the educator's confidence and hence skills of science education.

The activities presented here are based on Akihiko Tomita's visiting research at nurseries, kindergartens, preschools, and after school care clubs in Japan for about ten years; among them, especially Hikari Nursery and Osaka City Liaison Association of After School Care for practice, many educators and researchers including at Osaka Ohtani University for discussion. Part of the research has been supported by Japan Society for the Promotion of Science, Grants-in-Aid for Scientific Research, grant numbers 20500778 and 25350251.

\section{References}

1. A. Tomita: Astronomy Outreach Activity at Nursery School, Proceedings of the 11th Asian-Pacific Regional IAU Meeting (July 2011, Chiang Mai, Thailand), NARIT Conference Series, 1, 508-509 (2013)

2. A. Tomita: Evening Sky Watching for Students: Let's observe the evening sky with the naked eye, astroEDU, DOI: 10.14586/astroedu/1616 (2016)

3. A. Tomita: "Star Program" at After-School Day Care Clubs for Primary School Children, Bulletin of the Center for Educational Research and Training, Faculty of Education, Wakayama University, 25, 33-41 (2015)

4. C. Scorza and G. Kimble, EU-Universe Awareness Programme Evaluation Guide, ISBN: 9789491760037 (2013) 